\title{
Pengaruh Kepribadian Openness dan Agreeableness Terhadap Intensi Berbagi Pengetahuan pada Karyawan Perum LPPNPI (AirNav Indonesia) Cabang Madya Surabaya
}

\author{
Selly Dian Widyasari, Ridwan Aji Budi Prasetyo, Rahadijaya Arman Pusponegoro \\ sellydianpsi@ub.ac.id
}

Jurusan Psikologi, Universitas Brawijaya, Malang, Indonesia

\begin{abstract}
This study aims to investigate the effect of openness and agreeableness personalities to the intention of knowledge sharing. This study applied quantitative approach using multiple regression technique for hypothesis testing. Eighty-five employees of Perum LPPNPI Surabaya Branch (total sampling), particularly those who serve as air traffic controllers, participated in this study. Data necessary for this study was collected using Big-Five Inventory Scale that has been adapted to Bahasa Indonesia by Ramdhani (2012) and Knowledge Sharing Scale by Al Qeisi and Al Zagheer (2015). Simultaneous multiple regression analysis showed the significant effect of both types of personalities to the knowledge sharing intention. Meanwhile, partial regression analysis showed the significant effect only for openness personality, and not for agreeableness personality. Analysis on the psychological dynamic regarding the results was also discussed.
\end{abstract}

Penelitian ini bertujuan untuk mengetahui pengaruh tipe kepribadian openness dan agreeableness terhadap intensi berbagi pengetahuan. Penelitian ini menggunakan pendekatan kuantitatif dengan teknik regresi linier berganda untuk pengujian hipotesisnya. Sampel penelitian ini sebanyak 85 orang karyawan Perum LPPNPI Cabang Madya Surabaya (total sampling), khususnya yang bekerja sebagai pemandu lalu lintas udara (PLLU). Data yang diperlukan pada penelitian ini dikumpulkan menggunakan Skala Big-Five Inventory yang telah diadaptasi ke dalam Bahasa Indonesia oleh Ramdhani (2012) dan Skala Berbagi Pengetahuan dari Al Qeisi dan Al Zagheer (2015). Analisis regresi berganda secara simultan menunjukkan terdapat pengaruh yang signifikan antara openness dan agreeableness terhadap intensi berbagi pengetahuan. Analisis regresi secara parsial menunjukkan hasil bahwa antara openness dan intensi berbagi pengetahuan terdapat pengaruh yang signifikan, sedangkan antara agreeableness dan intensi berbagi pengetahuan tidak terdapat pengaruh. Analisis mengenai kemungkinan dinamika psikologis terkait hasil tersebut juga didiskusikan.

Kata kunci: agreeableness; intensi berbagi pengetahuan; openness

Received: August 1, 2017 Accepted: December 23, 2017

How to cite: Widyasari, S. D., Prasetyo, R. A. B., \& Pusponegoro, R. A. (2017). Pengaruh kepribadian openness dan agreeableness terhadap intensi berbagi pengetahuan pada karyawan Perum LPPNPI (AirNav Indonesia) Cabang Madya Surabaya. MEDIAPSI, 3(2), 39-48.

doi:http://dx.doi.org/10.21776/ub.mps.2017.003.02.5

\section{Pendahuluan}

Sumber Daya Manusia (SDM) telah menjadi bagian yang tidak terpisahkan dalam menjalankan roda operasional dan bisnis bagi setiap perusahaan dalam mencapai tujuantujuan yang telah disepakati bersama. Sebuah sistem sumber daya yang baik tidak hanya berfokus pada aspek-aspek manajemen semata seperti penilaian kinerja, penggajian, tunjangan, bonus, ataupun fasilitas nonfinansial lainnya yang diberikan oleh perusahaan. Saat ini, pengetahuan yang dimiliki oleh setiap karyawan juga telah menjadi perhatian manajemen perusahaan. Paradigma baru dalam sistem manajemen sumber daya manusia telah menjadikan pengetahuan atau knowledge sebagai bagian dari aset perusahaan. Pengetahuan yang dimiliki oleh karyawan diharapkan akan 
menciptakan kinerja yang lebih baik dan dapat meningkatkan iklim persaingan dalam perusahaan demi mendapatkan hasil yang terbaik. Pengetahuan juga merupakan sumber potensial dan memiliki keunggulan kompetitif karena bersifat unik dan tidak dapat digantikan ataupun diimitasi oleh orang lain (Nanda, 1996).

Oleh karena itu, berbagi pengetahuan (knowledge sharing) dapat menjadi hal yang sangat penting bagi perusahaan sebagai fungsi dalam mengembangkan keterampilan, kompetensi, meningkatkan nilai, serta sebagai sarana dalam mempertahankan sebuah keunggulan kompetitif. Organisasi dapat menjadi media sumber pengetahuan yang memiliki fungsi dalam integrasi pengetahuan dari setiap individu dalam proses produksi barang atau jasa. Berbagi pengetahuan juga dapat mengurangi biaya produksi, mempercepat pengembangan proyek baru, meningkatkan kinerja tim, menambah kapabilitas, menaikkan pertumbuhan penjualan, dan memperbesar penerimaan keuntungan dari produk dan layanan baru (Arthur \& Huntley, 2005; Collins \& Smith, 2006; Cummings, 2004; Hansen, 2002; Mesmer-Magnus \& Dechurch, 2009).

Jenis pengetahuan secara khusus dapat dibagi menjadi tacit knowledge dan explicit knowledge. Perbedaan antara dimensi tacit dan dimensi explicit dari pengetahuan terletak pada cara mengartikulasikannya Explicit knowledge, secara ringkas, merupakan pengetahuan yang terdiri dari fakta-fakta, aturan, dan kebijakan yang dapat diartikulasikan dan dimodifikasi secara tertulis atau dalam bentuk simbol serta dapat dibagikan dengan mudah itu, tacit knowledge adalah pengetahuan yang tidak disadari dan tidak diartikulasikan. Pengetahuan jenis ini melekat pada pikiran, pengalaman fisik, kemampuan gerak, intuisi, maupun aturanaturan dalam rutinitas yang bersifat praktis dan implisit (Zaim, Gurcan, Tarim, Zaim, \& Alpkan, 2015).

Menjadi "tahu" atau memiliki pengetahuan adalah suatu proses, yang dapat dilihat sebagai tindakan menggabungkan pengetahuan tacit dan explicit dalam tindakan tertentu (Tsoukas \& Vladimirou, 2001). Pengetahuan merupakan suatu hal yang tidak dapat dipisahkan dari tindakan karena pengetahuan akan selalu didasari oleh tindakan. Dengan demikian, berbagi pengetahuan akan melibatkan transfer suatu pengetahuan dari satu konteks tertentu ke konteks lainnya (Orlikowski, 2002).

Individu yang ingin berbagi pengetahuan harus memiliki intensi atau niat untuk melakukannya, karena intensi merupakan prasyarat utama dari perilaku berbagi pengetahuan (Wann-Yih \& Badri, 2010). Secara umum, intensi merupakan indikasiindikasi atau isyarat kesiapan seseorang untuk melakukan suatu perilaku (Ajzen \& Fishbein, 2008). Dalam beberapa penelitian sebelumnya, intensi berbagi pengetahuan kemudian secara spesifik didefinisikan sebagai kemauan atau keinginan untuk berbagi pengetahuan. Sementara itu, Baharim (2008) mendefinisikannya sebagai kemauan pekerja dalam menyumbangkan pengetahuan kepada rekanrekan kerjanya. Intensi untuk berbagi pengetahuan selanjutnya dipengaruhi oleh beberapa faktor yang berbeda-beda sesuai dengan konteksnya, seperti prinsip timbal balik, kontrol perilaku, kepercayaan (Lee \& Hong, 2014), kepribadian (Cui, 2017; Cabrera, Collins, \& Salgado, 2006), budaya organisasi, ketersediaan teknologi (Shabrina \& Silvianita, 2015), termasuk juga ketakutan terhadap klaim 
orang lain terhadap pengetahuan yang dimilikinya (Park \& Gabbard, 2018).

Secara khusus, kaitan antara kepribadian dan intensi untuk berbagi pengetahuan telah banyak diteliti sebelumnya pada berbagai konteks kerja, terutama dengan menggunakan perspektif The Five-Factor Model (FFM). Cabrera, dkk. (2006), misalnya, menyimpulkan bahwa dua dimensi dari FFM yaitu agreeableness dan openness memiliki kecenderungan positif yang signifikan terhadap intensi berbagi pengetahuan. Sementara itu, Cui (2017) meneliti intensi berbagi pengetahuan pada profesional teknologi informasi (IT) dan menemukan bahwa semua dimensi FFM memiliki pengaruh terhadap knowledge sharing kecuali pada dimensi extraversion.

Kelima dimensi FFM memiliki karakteristik yang berbeda. Secara ringkas, agreeableness cenderung menyenangkan (Besser \& Shackelford, 2007) karena berorientasi pada orang lain, seperti menolong, berbuat baik, memaafkan, dan mengapresiasi (McCrae \& John, 1992). Extraversion cenderung memiliki karakter untuk menjadi orang yang suka bergaul (Besser \& Shackelford, 2007), sedangkan conscientiousness cenderung memiliki sikap ketergantungan yang tinggi pada orientasi penghargaan dan karakter yang keras. Neuroticism cenderung memiliki kecenderungan mood negatif yang berbeda-beda seperti gelisah, sedih, dan tidak percaya. Sementara itu, openness to experience memiliki karakteristik pikiran yang terbuka dan berseni (Thoms, Moore, \& Scott, 1996).

Pada penelitian ini, dua dimensi FFM, yaitu agreeableness dan openness, diduga berkaitan erat dengan intensi berbagi pengetahuan. Hal tersebut disimpulkan dari karakteristik-karakteristik kedua dimensi tersebut yang nampaknya akan berkaitan dengan intensi berbagi pengetahuan. Seorang yang dominan pada dimensi agreeableness cenderung memiliki karakteristik baik hati, pemaaf, sopan, penolong, murah hati, ceria, dan bisa diajak bekerja sama (Barrick \& Mount, 1991). Selain itu, individu dengan agreeableness tinggi juga cenderung altruistik, simpatik, dan antusias untuk membantu orang lain, serta lebih cenderung untuk bekerja sama daripada berkompetisi (Liao \& Chuang, 2004). Cabrera, dkk. (2006) menambahkan bahwa individu yang agreeable cenderung kooperatif, penolong, dan membantu yang lain. Oleh karena adanya sifat-sifat seperti itu, dalam konteks pekerjaan, individu yang agreeable diduga kuat memiliki intensi yang tinggi dalam berbagi pengetahuan.

Sementara itu, individu dengan openness yang tinggi cenderung memiliki rasa ingin tahu yang tinggi. Mereka juga dapat memberikan ide-ide serta nilai-nilai baru yang tidak biasa atau konvensional keterbukaan (Costa \& McCrae, 1992). Selain itu, individu yang open memiliki karakteristik yang dapat menampilkan keingintahuan intelektualitas yang kuat, kreativitas, dan fleksibilitas berpikir (Digman, 1990), sehingga cenderung memiliki sikap yang lebih positif untuk belajar hal-hal baru dan intensi yang lebih tinggi untuk terlibat dalam pengalaman pembelajaran (Barrick \& Mount, 1991). Cabrera, dkk. (2006) menemukan bahwa keterbukaan adalah prediktor kuat dalam berbagi pengetahuan karena keterbukaan terhadap pengalaman adalah refleksi dari rasa ingin tahu seseorang dan keinginan untuk mencari wawasan dari orang lain. Individu seperti itu juga cenderung berkontribusi lebih dalam mencari ilmu (Wasko \& Faraj, 2000, 2005). 
Penelitian ini mengambil konteks pada Perusahaan Umum Lembaga Penyelenggara Pelayanan Navigasi Penerbangan Indonesia (Perum LPPNPI), yang dikenal juga sebagai AirNav Indonesia. Perum LPPNPI merupakan perusahaan milik negara (BUMN) yang menyelenggarakan dan melayani navigasi penerbangan di ruang udara Indonesia. Dalam konteks pekerjaan pemandu lalu lintas udara (PLLU) atau air traffic controller (ATC), berbagi pengetahuan mungkin diperlukan karena tiap pemandu memiliki pengalaman atau jam terbang yang berbeda-beda. Pekerjaan PLLU juga cenderung individualistik yang mana antara satu pemandu dengan pemandu lainnya bertanggung jawab atas ruang udaranya masing-masing sehingga minim interaksi dengan sesamanya. Pemandu akan lebih banyak memperhatikan layar monitor masing-masing dan berkomunikasi dengan para pilot di udara. Walaupun pekerjaan ini dilakukan berdasarkan prosedurprosedur dan aturan-aturan paten dari otoritas penerbangan sipil internasional (ICAO) maupun Direktorat Jenderal Perhubungan Udara, tetap ada ruang improvisasi yang terbatas dalam menjalankan pekerjaannya dan hal ini memerlukan pengetahuan yang memadai. Oleh karena itu, transfer pengetahuan, terutama yang bersifat tacit, tetap diperlukan agar proses memandu lalu lintas udara ini dapat berjalan efektif dan efisien (semakin banyak pesawat yang dilayani) namun tetap sesuai prosedur dan aturan yang berlaku.

Seperti yang disampaikan sebelumnya, dua dimensi kepribadian FFM, yaitu agreeableness dan openness, berkaitan erat dengan intensi berbagi pengetahuan karena karakteristik kedua dimensi tersebut diduga kuat mendukung untuk terjadinya intensi tersebut. Dengan demikian, penelitian ini bertujuan untuk melihat pengaruh kepribadian openness dan agreeableness dengan intensi berbagi pengetahuan.

\section{Metode}

\section{Desain penelitian}

Penelitian ini menggunakan pendekatan kuantitatif dengan pendekatan regresi linier berganda untuk melihat pengaruh antara satu variabel terhadap variabel lainnya.

\section{Responden}

Sampel dalam penelitian ini adalah karyawan Divisi Pelayanan Lalu Lintas Udara Perum LPPNPI Cabang Madya Surabaya sebanyak 85 orang. Adapun teknik sampling yang digunakan pada penelitian ini adalah total sampling, yaitu penentuan jumlah sampel yang sama dengan jumlah populasi (Sugiyono, 2011).

\section{Instrumen penelitian}

Data pada penelitian ini diambil dengan menggunakan Skala Big-Five Inventory yang telah diadaptasi oleh Ramdhani (2012) yang terdiri dari 44 butir, yang mana 10 butir di antaranya mengukur dimensi openness $(\alpha=0.807)$ dan 9 butir lainnya mengukur dimensi agreeableness $(\alpha=0.704)$. Skala tersebut bertujuan untuk mengidentifikasi kecenderungan kepribadian karyawan pada kedua dimensi tersebut.

Sementara itu, Skala Intensi Berbagi Pengetahuan dari Al Qeisi dan Al Zagheer (2015) digunakan untuk mengukur intensi atau niat individu untuk melakukan perilaku bertukar pengetahuan baik antar individu maupun antara individu dengan kelompok. Skala tersebut terdiri dari 13 butir $(\alpha=0.784)$ yang dikembangkan dari teori perilaku terencana (theory of planned behavior) dari Ajzen. 


\section{Teknik analisis data}

Data yang diperoleh pada penelitian ini kemudian dianalisis dengan teknik analisis regresi linier berganda (multiple regression) dengan bantuan software SPSS for Windows versi 20. Sebelum melakukan uji hipotesis dengan teknik tersebut, terlebih dahulu dilakukan uji normalitas dan uji linieritas untuk melihat kecenderungan data.

\section{Hasil}

\section{Analisis deskriptif}

Analisis deskriptif dilakukan terhadap beberapa aspek demografis yaitu usia, lama bekerja, dan jenis kelamin. Sebagaimana yang dapat dilihat pada Tabel 1, karyawan Perum LPPNPI Cabang Madya Surabaya didominasi oleh laki-laki (60 orang; 71\%). Pemandu yang berjenis kelamin perempuan hanya terdapat 25 orang (29\%). Dalam kaitannya dengan usia PLLU, rentang usia 31-40 tahun merupakan yang terbanyak (40\%), sedangkan rentang usia 51-60 adalah yang paling sedikit (12\%). Sementara itu, rentang masa kerja terbanyak adalah 11-20 tahun (48\%) dan paling sedikit 51-60 tahun (7\%).

Tabel 1

Data Demografis PLLU Cabang Madya Surabaya

\begin{tabular}{llcc}
\hline & Kategori & $\begin{array}{c}\text { Jumlah } \\
\text { (orang) }\end{array}$ & Persentase \\
\hline Usia & $20-30$ tahun & 18 & $21 \%$ \\
& $31-40$ tahun & 34 & $40 \%$ \\
& $41-50$ tahun & 23 & $27 \%$ \\
& $51-60$ tahun & 10 & $12 \%$ \\
\hline Lama & $0-10$ tahun & 21 & $25 \%$ \\
bekerja & $11-20$ tahun & 41 & $48 \%$ \\
& $21-30$ tahun & 17 & $20 \%$ \\
& $31-40$ tahun & 6 & $7 \%$ \\
\hline Jenis & Laki-laki & 60 & $71 \%$ \\
\hline kelamin & Perempuan & 25 & $29 \%$ \\
\hline
\end{tabular}

\section{Uji normalitas}

Uji normalitas digunakan untuk mengetahui apakah pendistribusian data variabel-variabel penelitian bersifat normal atau tidak. Uji normalitas diuji dengan menggunakan teknik One-Sample Kolmogorov-Smirnov. Variabel dapat dikatakan berdistribusi normal apabila mendapatkan nilai signifikansi $\mathrm{p}>0.05$.

Tabel 2

Hasil Analisis Uji Normalitas

\begin{tabular}{lccc}
\hline \multicolumn{1}{c}{ Variabel } & $\begin{array}{c}\text { Kolmogorov- } \\
\text { Smirnov }\end{array}$ & Sig. & Ket. \\
\hline Openness & 1.150 & 0.142 & Normal \\
Agreeableness & 1.294 & 0.365 & Normal \\
$\begin{array}{l}\text { Intensi } \\
\begin{array}{l}\text { Berbagi } \\
\text { Pengetahuan }\end{array}\end{array}$ & 1.215 & 0.104 & Normal \\
\hline
\end{tabular}

Dari hasil uji normalitas seperti yang dipaparkan pada Tabel 1, dapat diketahui bahwa sebaran skor variabel X1 (openness) memiliki sebaran yang normal dengan nilai signifikansi uji Kolmogorov-Smirnov (KS) sebesar 1.150 dan signifikansi 0.142, sedangkan pada variabel X2 (agreeableness) diperoleh nilai signifikansi uji KolmogorovSmirnov (KS) sebesar 1.294 dan signifikansi 0.365 . Sementara itu, pada variabel Y (Intensi Berbagi Pengetahuan) diperoleh nilai signifikansi uji Kolmogorov-Smirnov (KS) sebesar 1.215 dengan signifikansi 0.104. Berdasarkan uji normalitas, selanjutnya dapat disimpulkan bahwa variabel openness, agreeableness, dan intensi berbagi pengetahuan mengikuti distribusi normal.

\section{Uji linieritas}

Uji asumsi kedua yang dilakukan adalah uji linieritas, yang mana uji ini bertujuan untuk mengetahui apakah ketiga variabel dapat berkorelasi secara linier atau tidak (Siregar, 2013). Berdasarkan hasil uji linieritas 
(selengkapnya pada Tabel 3), dapat diketahui bahwa korelasi antara variabel openness dengan variabel intensi berbagi pengetahuan memiliki nilai $\mathrm{F}$ sebesar 1.273 dan nilai signifikansi 0.244 , sedangkan antara variabel agreeableness dengan intensi berbagi pengetahuan memiliki nilai $\mathrm{F}$ sebesar 1.307 dan nilai signifikansi sebesar 0.238. dengan demikian, dapat dikatakan bahwa hubungan antara variabel openness dan intensi berbagi pengetahuan serta antara variabel agreeableness dan intensi berbagi pengetahuan bersifat linier.

Tabel 3

Hasil Uji Linieritas

\begin{tabular}{lccc}
\hline \multicolumn{1}{c}{ Variabel } & Nilai F & Sig. & Ket. \\
\hline $\begin{array}{l}\text { Openness dengan } \\
\text { intensi berbagi } \\
\text { pengetahuan }\end{array}$ & 1.273 & 0.244 & Linier \\
\hline $\begin{array}{l}\text { Agreeableness } \\
\text { dengan intensi } \\
\text { berbagi } \\
\text { pengetahuan }\end{array}$ & 1.307 & 0.238 & Linier \\
\hline
\end{tabular}

\section{Uji hipotesis}

Pengujian hipotesis dalam penelitian ini dilakukan dengan menggunakan teknik regresi linier berganda atau multiple regression. Adapun persamaan regresinya yaitu:

$$
Y=29.716+0.315 X_{1}+0.007 X_{2}
$$

Berdasarkan hasil uji regresi simultan diperoleh keterangan mengenai pengaruh variabel openness dan agreeableness dengan variabel intensi berbagi pengetahuan sebesar 0.125 dengan nilai signifikansi 0.04, yang bermakna terdapat pengaruh antar variabel secara simultan. Sementara itu, berdasarkan hasil uji regresi parsial, diperoleh pengaruh antara variabel openness dengan variabel intensi berbagi pengetahuan sebesar 0.315 dengan nilai signifikan 0.001, yang berarti bahwa terdapat pengaruh yang signifikan antar variabel secara parsial. Pengaruh antara variabel agreeableness dengan variabel intensi berbagi pengetahuan adalah sebesar 0.941 dengan nilai signifikan 0.007 , yang bermakna bahwa tidak terdapat pengaruh yang signifikan antar variabel secara parsial. Tabel 4 dan 5 memaparkan hasil uji regresi simultan dan parsial.

Tabel 4

Hasil Uji Regresi Simultan

\begin{tabular}{lccc}
\hline \multicolumn{1}{c}{ Variabel } & Sig. (p) & $\begin{array}{c}\text { Koefisien } \\
\text { Determinasi }\left(\mathbf{R}^{2}\right)\end{array}$ & Ket. \\
\hline $\begin{array}{l}\text { Openness, } \\
\text { agreeableness } \\
\text { terhadap } \\
\text { intensi berbagi } \\
\text { pengetahuan }\end{array}$ & 0.004 & 0.125 & Diterima \\
\hline $\begin{array}{l}\text { Tabel 5 } \\
\text { Hasil Uji Regresi Parsial }\end{array}$ & & \\
\hline \multicolumn{1}{c}{ Variabel } & Sig. (p) & Nilai Beta (B) & Ket. \\
\hline $\begin{array}{l}\text { Openness } \\
\text { terhadap intensi } \\
\text { berbagi } \\
\text { pengetahuan }\end{array}$ & 0.001 & 0.315 & Diterima \\
\hline $\begin{array}{l}\text { Agreeableness } \\
\text { terhadap intensi } \\
\text { berbagi } \\
\text { pengetahuan }\end{array}$ & 0.007 & 0.941 & Tidak \\
\hline
\end{tabular}

\section{Diskusi}

Tujuan dari penelitian ini adalah untuk mengetahui pengaruh tipe kepribadian openness dan agreeableness terhadap intensi berbagi pengetahuan. Uji hipotesis secara simultan menunjukkan adanya pengaruh yang signifikan antara openness dan agreeableness terhadap intensi berbagi pengetahuan. Semakin tinggi dimensi openness dan agreeableness, maka intensi berbagi pengetahuan juga semakin tinggi. Sebaliknya, jika openness dan agreeableness seseorang rendah, maka intensi berbagi pengetahuannya juga rendah. 
Hasil penelitian tersebut mununjukkan bahwa bahwa sikap open dan agreeable saling berkaitan dan mendukung dalam proses terjadinya intensi berbagi pengetahuan pada personil PLLU di Perum LPPNPI Cabang Madya Surabaya. Hal ini besar kemungkinan karena karakteristik dari kedua tipe kepribadian tersebut. Tupes dan Christal (1992) individu dengan openness tinggi senang berbagi informasi baru. McCrae dan Costa (1996) menambahkan bahwa individu dengan openness tinggi akan memiliki rasa ingin tahu yang tinggi pula. Cui (2017) juga menyatakan bahwa individu yang open cenderung memiliki sikap yang lebih positif terhadap berbagi pengetahuan dan berpartisipasi dalam pengalaman pembelajaran meskipun mereka tidak secara khusus diminta untuk melakukannya. Sementara itu, individu yang agreeable adalah individu yang dapat bekerja sama (Tupes \& Christal, 1992) serta memiliki kecenderungan interpersonal yang tinggi (McCrae \& Costa, 1996).

Saat bekerja, PLLU akan berfokus pada layar monitor ataupun flight progress strip yang ada di hadapannya dan berkomunikasi secara intensif dengan pilot yang berada di wilayah udara yang menjadi tanggung jawabnya. Dengan karakteristik pekerjaan yang demikian, proses saling transfer pengetahuan lebih dimungkinkan terjadi ketika di luar shift kerja mereka. Sesama PLLU dapat saling bertukar pengalaman dalam memandu pesawat udara di kategori ruang udara yang berbeda-beda, terutama saat menghadapi situasi yang tidak biasa dan membutuhkan pengambilan keputusan yang cepat dan segera, seperti technical ataupun medical emergency. Dalam menghadapi situasi yang seperti itu, transfer pengetahuan mungkin diperlukan terutama untuk PLLU junior yang masih sedikit jam terbangnya. Dinamika kerja seperti itu akan terfasilitasi dengan baik jika sesama PLLU memiliki openness dan agreeableness yang tinggi dan saling berinteraksi.

Selanjutnya, uji hipotesis parsial antara openness dan intensi berbagi pengetahuan memberikan hasil bahwa terdapat pengaruh yang signifikan antar variabel secara parsial, sedangkan antara agreeableness dan intensi berbagi pengetahuan dapat disimpulkan bahwa tidak ada pengaruh yang signifikan antar kedua variabel tersebut. Hasil ini di saat yang bersamaan sesuai dan tidak sesuai dengan beberapa penelitian terdahulu. Hasil penelitian ini, misalnya, sedikit berbeda dengan penelitian Cabrera, dkk (2006) yang menyatakan bahwa openness dan agreeableness merupakan prediktor bagi intensi berbagi pengetahuan. Cui (2017) juga memaparkan hasil yang serupa dalam penelitiannya dalam konteks profesional IT, yaitu semua tipe kepribadian Big-Five, kecuali extraversion, berpengaruh terhadap kecenderungan berbagi pengetahuan.

Hal ini mungkin dapat dijelaskan dengan melihat pada konteks pekerjaan PLLU. Dengan model tugas-tugas yang cenderung telah dijelaskan secara terperinci dan paten dalam prosedur maupun aturan yang disepakati secara internasional, ditambah fokus kerja yang terbatas pada monitor dan komunikasi dengan pilot, PLLU cenderung bekerja secara individualistik. Mereka msingmasing telah mengetahui apa yang harus mereka lakukan berdasarkan pendidikan dan training yang mereka telah dapatkan, juga prosedur dan aturan yang telah mereka baca dan pelajari. Hal ini menjadikan inisiatif untuk menolong, yang menjadi salah satu ciri individu dengan agreeableness, relatif memiliki ruang yang terbatas pada konteks pekerjaan ini, kecuali pada kondisi-kondisi 
tertentu. Pada akhirnya, keberadaan atau ketiadaan agreeableness pada diri individu tidak memiliki kontribusi yang signifikan terhadap intensi untuk berbagi pengetahuan.

Kendati demikian, ruang untuk berbagi pengetahuan tetap terbuka pada konteks pekerjaan PLLU. Hal ini dibuktikan melalui hasil penelitian ini yang menyatakan bahwa PLLU yang memiliki openness tinggi cenderung memiliki intensi berbagi pengetahuan. Pada konteks ini, sebagaimana yang telah dijelaskan sebelumnya, proses saling transfer pengetahuan lebih dimungkinkan terjadi ketika di luar shift kerja mereka. Sesama PLLU dapat saling bertukar pengalaman dalam memandu pesawat udara di kategori ruang udara yang berbeda-beda, terutama saat menghadapi situasi yang tidak biasa dan membutuhkan pengambilan keputusan yang cepat dan segera. Jika kembali melihat pada analisis deskriptif pada aspek demografis PLLU di Perum LPPNPI Cabang Madya Surabaya, umumnya mereka berada di rentang usia 20-40 tahun dengan masa kerja berkisar mulai dari 0 sampai 20 tahun. Mereka dapat dikategorikan ke dalam pekerja-pekerja yang berada di tahap awal sampai tengah karir yang tentunya memerlukan transfer pengetahuan secara baik agar dapat menjalankan peran dalam profesinya dengan baik pula. Kepribadian yang open akan memfasilitasi proses tersebut sehingga dapat berjalan dengan lancar.

Penelitian ini tentu memiliki keterbatasan. Salah satu keterbatasan yang paling utama adalah lokasi penelitian yang merupakan area terbatas (restricted area) di mana tidak semua orang dapat mengaksesnya. Hal ini dapat dipahami karena keselamatan penerbangan salah satunya diciptakan dari ruang kerja para PLLU tersebut. Hal tersebut kemudian membuat proses pengambilan data berlangsung cukup lama.

Adapun saran terkait dengan hal ini, bagi penelitian serupa di masa mendatang dapat mempertimbangkan untuk mengambil sampel pada bandara-bandara lain, termasuk bandarabandara kecil atau perintis yang tidak dikelola oleh Perum LPPNPI. Hal tersebut akan menarik karena karakteristik kerja dari PLLU di bandara-bandara kecil sedikit berbeda, dari sisi ketersediaan teknologi, sumber daya manusia, dan intensitas lalu lintas udaranya.

Pada akhirnya dapat disimpulkan bahwa berdasarkan hasil penelitian ini,

1. Terdapat pengaruh tipe kepribadian openness dan agreeableness terhadap intensi berbagi pengetahuan.

2. Terdapat pengaruh tipe kepribadian openness terhadap intensi berbagi pengetahuan.

3. Tidak terdapat pengaruh tipe kepribadian agreeableness terhadap intensi berbagi pengetahuan.

\section{Daftar Pustaka}

Ajzen, I., \& Fishbein, M. (2010). Predicting and Changing Behavior: The Reasoned Action Approach. New York: Taylor \& Francis Group.

Al Qeisi, K. I., \& Al Zagheer, H. M. (2015). Determinats of knowledge sharing behaviour among personnel in banking industry. International Journal of Business and Management, 10(4), 4959.

Arthur, J. B., \& Huntley, C. L. (2005). Ramping up the organizational learning curve: assessing the impact of deliberate 
learning on organization performance under gainsharing. Academy of Management Journal, 48(6), 1159-1170.

Baharim, S. B. (2008). The influence of knowledge sharing on motivation to transfer training: a Malaysian public sector context. Disertasi. Victoria University, Australia.

Barrick, M. R., \& Mount, M. K. (1996). Effect on impression management and selfdeception on the predictive validity of personality constructs. Journal of Applied Psychology, 81(3), 261-272.

Besser, A., \& Shackelford, T. K. (2007). Mediation of the effects of the big five personality dimensions on negative mood and comfirmed affective expectations by perceived situational stress: a quasi-field study of vacationers. Personality and Individual Differences, 42(7), 1333-1346.

Cabrera, A., Collins, W. C., \& Salgado, J. F. (2006). Determinant of individual engagement in knowledge sharing. International Journal of Human Resource Management, 17(2), 245-264.

Collins, C. J., \& Smith, K. G. (2006). Knowledge exchange and combination: the role of human resource practice in the performance of high-technology firms. Academy of Management Journal, 49(3), 544-560.

Costa, P. T., \& McCrae, R. R. (1992). Revised NEO Personality Inventory and NEO Five-Factor Inventory. Odessa, FL: Psychological Assessment Resources.

Cui, X. (2017). In- and extra-role knowledge sharing among information technology professionals: the five-factor model perspective. International Journal of Information Management, 37(5), 380389.

Cummings, J. N. (2004). Work groups, structural diversity, and knowledge sharing in a global organization. Management Science, 50(3), 352-364.

Digman, J. M. (1990) Personality structure: emergence of the Five-Factor Model. Annual Review of Psychology, 41, 417440.

Hansen, M. T. (2002). Knowledge network: explaining effective knowledge sharing in multiunit companies. Organization Science, 13(3), 232-248.

Lee, H. S., \& Hong, S. A. (2014). Factors affecting hospital employees' knowledge sharing intention and behavior, and innovation behavior. Osong Public Health and Research Perspectives, 5(3), 148-155.

Liao, H., \& Chuang, A. (2004). A multilevel investigation of factors influencing employee service performance and customer outcomes. Academy of Management Journal, 47(1), 41-58.

McCrae, R. R., \& Costa, P. T. (1996). Toward a new generation of personality theories: theoretical contexts for The Five-Factor Model. Dalam J. S. Wiggins (Ed.), The Five-Factor Model of personality: Theoretical perspectives (hal. 51-87). New York: Guilford Press.

Mesmer-Magnus, J. R., \& Dechurch, L. A. (2009). Information sharing and team performance: a meta-analysis. Journal of Applied Psychology, 94(2), 535-546.

Nanda, A. (1996). Resources, capabilities, and competencies. Dalam B. Moingeon \& A. 
Edmonson (Eds.), Organizational learning and competitive advantage (hal. 93-120). London: Sage.

Orlikowski, W. J. (2002). Knowing in practice: enacting a collective capability in distributed organizing. Organization Science, 13(3), 249-273.

Park, J., \& Gabbard, J. L. (2018). Factors that affect scientists' knowledge sharing behavior in health and life sciences research communities: differences between explicit and implicit knowledge. Computers in Human Behavior, 78, 326-335.

Ramdhani, N. (2012). Adaptasi Bahasa dan Budaya Inventori Big Five. Jurnal Psikologi, 39(2), 189-207.

Shabrina, V., \& Silvianita, A. (2015). Factors analysis on knowledge sharing at Telkom Economic and Business School (TEBS) Telkom University Bandung. Procedia Social and Behavioral Sciences, 169, 198-206.

Siregar, S. (2013). Statistik Parametrik untuk Penelitian Kuantitatif. Jakarta: Bumi Aksara.

Sugiyono. (2011). Metode Penelitian Kuantitatif, Kualitatif, dan R\&D. Bandung: Afabeta.

Thoms, P., Moore, K. S., \& Scott, K. S. (1996). The relationship between self-efficacy for participating in self-managed work groups and the big personality dimensions. Journal of Organizational Behaviour, 17(4), 349-362.

Tsoukas, H., \& Vladimirou, E. (2001). What is organizational knowledge? Journal of Management Studies, 38(7), 973-993.

Tupes, E. C., \& Christal, R. E. (1992).
Recurrent personality factors based on trait ratings. Journal of Personality, 60(2), 225-251.

Wann-Yih, W., \& Badri, M. (2010). Why should I share? examining consumers' motives and trust on knowledge sharing. Journal of Computer Systems, 50(4), 1119.

Wasko, M. M., \& Faraj, S. (2000). "It is what one does": why people participate and help others in electronic communities of practice. Journal of Strategic Information Systems, 9(2-3), 155-173.

Wasko, M. M., \& Faraj, S. (2005). Why should I share? examining social capital and knowledge contribution in electronic networks of practice. MIS Quarterly, 29(1), 35-57.

Zaim, H., Gurcan, O. F., Tarim, M., Zaim, S., \& Alpkan, L. Determining the critical factors of tacit knowledge in service industry in Turkey. Procedia Social and Behavioral Sciences, 207, 759-767. 